JSAP: Journal Syariah and Accounting Public

ISSN: 2622-3538

Available Online at https://journal.umgo.ac.id/index.php/JSAP/index

Vol. 3, No. 2 Desember 2020

DOI: $10.31314 /$ jsap.3.2.66-73.2020

\title{
PERAN BUMDES DALAM MENINGKATKAN EKONOMI MASYARAKAT DI DESA AYUHULA KECAMATAN DUNGALIYO KABUPATEN GORONTALO
}

\author{
Umar Sako Baderan 1 , Budiyanto Napu ${ }^{2}$ \\ 1,2, Program Studi Administrasi Publik Universitas Muhammadiyah Gorontalo Indonesia \\ Email; USBaderan@umgo.ac.id, budiyantonapu@umgo.ac.id
}

Info Artikel: Diterima: 13 Oktober 2020, Disetujui: 23 November 2020, Publish 15 Desember 2020

\begin{abstract}
:
This study aims to determine how the role of BUMDes in Improving Community Economy in Ayuhula Village, Dungaliyo District, Gorontalo Regency. This research is included in the type of descriptive research with a qualitative research approach. The results of the research show that the active role in the aspect of enhancing the quality of human and community life can be found in this aspect to be able to help socially but economically yet to play a role; In the aspect of strengthening the people's economy as the basis for the strength and resilience of the national economy with BUMDes as its foundation, it is found that BUMDes currently has limited capital so this is quite difficult in doing business expansion; In the apsek trying to realize and develop the economy of the village community, obtained with the limitations owned by BUMDes making it difficult to develop businesses related to the potential of the village: and in the aspect of helping the community to increase their income so as to increase the income and prosperity of the community, found where there is pessimism from the village government that $B U M D e s$ managers have not been able to if the businesses in BUMDes have increased.
\end{abstract}

Keywords: Role, BUMDes, Community Economy

\begin{abstract}
Abstrak:
Penelitian ini bertujuan untuk mengetahui bagaimana Peran BUMDes dalam Meningkatkan Ekonomi Masyarakat di Desa Ayuhula Kecamatan Dungaliyo Kabupaten Gorontalo. Penelitian ini termasuk dalam jenis penelitian deskriptif dengan pendekatan penelitian kualitatif. Hasil penelitian bahwa Pada aspek berperan secara aktif dalam upaya mempertinggi kualitas kehidupan manusia dan masyarakat, didapatkan pada aspek ini secara sosial dapat membantu namu secara ekonomi belum bisa berperan; Pada aspek memperkokoh perekonomian rakyat sebagai dasar kekuatan dan ketahanan perekonomian nasional dengan BUMDes sebagai pondasinya, didapatkan bahwa BUMDes saat ini memiliki keterbatasan modal sehingga hal ini cukup menyulitkan dalam melakukan ekspansi usaha; Pada apsek berusaha untuk mewujudkan dan mengembangkan perekonomian masyarakat desa, didapatkan dengan adanya keterbatasan yang dimiliki BUMDes sehingga sulit untuk mengembangkan usaha yang terkait dengan potensi desa: dan pada aspek membantu para masyarakat untuk meningkatkan penghasilannya sehingga dapat meningkatkan pendapatan dan kemakmuran masyarakat, didapatkan dimana adanya pesimisme dari pemerintah desa bahwa pengelola BUMDes belum mampu jika usaha yang ada di BUMDes bertambah.
\end{abstract}

Kata kunci : Peran, BUMDes, Ekonomi Masyarakat 


\section{PENDAHULUAN}

Membangun Indonesia dari pinggiran itu berarti desa harus dibangun karena sebagian besar penduduk Indonesia ada didesa. Masyarakat desa harus diposisikan sebagai subjek atau pelaku dari pembangunan itu sendiri, sehingga masyarakat desa diberi kewenangan untuk dapat mendefenisikan kebutuhannya sendiri sehingga program dan kegiatan pembangunan desa harus menyentuh secara langsung kebutuhan masyarakat desa. Desa mempunyai wewenang yang penting dalam membantu pemerintah daerah dalam pelaksanaan pemerintahan, termasuk pembangunan di Desa. Salah satu program pemerintah dalam mendukung pembangunan desa yaitu dengan mengeluarkan Dana Desa sebagai salah satu sumber pendapatan desa

\section{Realisasi Dana Desa merupakan} tindak lanjut program pemerintah membangun Indonesia dari pinggiran dengan memperkuat daerah-daerah dan desa dalam kerangka negara kesatuan yang bertujuan untuk meningkatkan kesejahteraan dan pemerataan pembangunan melalui peningkatan pelayanan publik, memajukan perkonomian, mengatasi kesenjangan pembangunan antar desa serta memperkuat masyarakat sebagai subjek dari pembangunan. Tujuan pembangunan desa yaitu meningkatkan kesejahteraan masyarakat desa dan kualitas hidup manusia serta penanggulangan kemiskinan, melalui: pemenuhan kebutuhan dasar, pembangunan sarana dan prasarana desa, pengembangan potensi ekonomi lokal, serta pemanfaatan sumber daya alam dan lingkungan secara berkelanjutan.

Pengembangan basis ekonomi di pedesaan sudah semenjak lama dijalankan oleh pemerintah melalui berbagai program. Namun upaya itu belum membuahkan hasil yang memuaskan sebagaimana diinginkan bersama. Oleh karena itu pemerintah menerapkan pendekatan baru yang diharapkan mampu menstimulus dan menggerakkan roda perekonomian di pedesaan, salah satu upaya yang bisa dilakukan adalah dengan mendorong gerak ekonomi desa melalui kewirausahaan desa yang diwadahi dalam Badan Usaha Milik Desa (BUMDES) yang dikembangkan oleh pemerintah maupun masyarakat desa.

BUMDES merupakan lembaga usaha yang bergerak dalam bidang pengelolaan aset-aset dan sumberdaya ekonomi desa dalam kerangka pemberdayaan masyarakat desa. BUMDES diatur di dalam pasal 213 ayat (1) UU Nomor. 23 Tahun 2014, bahwa Desa dapat mendirikan Badan Usaha Milik Desa sesuai dengan kebutuhan dan potensi desa. Selain itu juga diatur dalam Peraturan Pemerintah Nomor 72 Tahun 2005 tentang Desa, serta yang terakhir dalam Peraturan Menteri Dalam Negeri Nomor 39 Tahun 2010 tentang Badan Usaha Milik Desa. BUMDes adalah badan usaha yang seluruh atau sebagian besar modalnya dimiliki oleh desa melalui penyertaan langsung yang berasal dari kekayaan desa yang dipisahkan guna mengelola aset, jasa pelayanan, dan usaha lain untuk sebesar-besarnya kesejahteraan masyarakat desa (Kamaroesid, 2015: 2).

Menurut Seyadi (2003:16) peranan BUMDes adalah sebagai berikut:

1. Membangun dan mengembangkan potensi dan kemampuan ekonomi masyarakat Desa, pada umumnya untuk meningkatkan kesejahteraan ekonomi dan sosialnya.

2. Berperan secara aktif dalam upaya mempertinggi kualitas kehidupan manusia dan masyarakat.

3. Memperkokoh perekonomian rakyat sebagai dasar kekuatan dan 
ketahanan perekonomian nasional dengan BUMDes sebagai pondasinya.

4. Berusaha untuk mewujudkan dan mengembangkan perekonomian masyarakat desa

5. Membantu para masyarakat untuk meningkatkan penghasilannya sehingga dapat meningkatkan pendapatan dan kemakmuran masyarakat

Pendirian dan pengelolaan Badan Usaha Milik Desa adalah merupakan perwujudan dari pengelolaan ekonomi produktif desa yang dilakukan secara kooperatif, partisipatif, emansipatif, transparansi, akuntabel, dan sustainable. Oleh karena itu, perlu upaya serius untuk menjadikan pengelolaan badan usaha tersebut dapat berjalan secara efektif, efisien, profesional dan mandiri untuk mencapai tujuan BUMDes dilakukan dengan cara memenuhi kebutuhan (produktif dan konsumtif) masyarakat melalui pelayanan distribusi barang dan jasa yang dikelola masyarakat dan PemDes. Pemenuhan kebutuhan ini diupayakan tidak memberatkan masyarakat, mengingat BUMDes akan menjadi usaha desa yang paling dominan dalam menggerakkan ekonomi desa. Lembaga ini juga dituntut mampu memberikan pelayanan kepada non anggota (di luar desa) dengan menempatkan harga dan pelayanan yang berlaku standar pasar. Artinya terdapat mekanisme kelembagaan/tata aturan yang disepakati bersama, sehingga tidak menimbulkan distorsi ekonomi di pedesaan disebabkan usaha yang dijalankan oleh BUMDES.

Observasi awal yang dilakukan oleh didapatkan bahwa BUMDES di Desa Ayuhula Kecamatan Dungaliyo yang telah diberdiri sejak 2 tahun yang lalu itu dianggap tidak memberikan kontribusi yang jelas dalam meningkatkan ekonomi masyarakat desa, padahal tujuan dibentuknya BUMDES salah satunya adalah bagaimana masyarakat yang ada di wilyahnya dapat meningkat ekonomi dan kesejahteraannya. Hal lain yang ditemukan pada saat dilakukan observasi adalah usaha bisnis yang di laksanakan oleh BUMDES adalah hanya usaha bisnis musiman seperti penyediaan kursi dan tenda pesta, hal ini pula yang sering dikeluhkan oleh masyarakat, harapan masyarakat adalah bahwa BUMDES mampu menciptakan unit bisnis yang menjadi kebutuhan masyarakat misalnya seperti: pengadaan pupuk, pengadaan bibit pertanian dan hal-hal yang menyangkut kebutuhan masyarakat berdasarkan profesi yang dijalankan yakni rata-rata berprofesi sebagai petani dan pekebun.

\section{METODE PENELITIAN}

Penelitian ini merupakan sebuah penelitian deskriptif dengan pendekatan kualitatif. Bogdan dan Taylor dalam Moloeng (2007:4) mendefinisikan penelitian kualitatif sebagai prosedur penelitian yang menghasilkan data deskriptif berupa katakata tertulis atau lisan dari orang-orang dan perilaku yang diamati dari fenomena yang terjadi. Lebih lanjut Moleong (2007:11) mengemukakan bahwa penelitian deskriptif menekankan pada data berupa kata-kata, gambar, dan bukan angka-angka yang disebabkan oleh adanya penerapan metode kualitatif. Selain itu, semua yang dikumpulkan berkemungkinan menjadi kunci terhadap apa yang sudah diteliti.

Data yang dikumpulkan dari penelitian ini berasal dari dua sumber, yaitu: 
a. Data primer, adalah data yang diperoleh langsung dari lapangan baik melalui observasi maupun melalui wawancara dengan pihak informan. Adapun yang menjadi Informan dalam penelitian ini adalah :

- Kepala Desa 1 orang

- Sekretaris Desa 1 orang

- Pengelola BUMDES 3 orang

- Masyarakat 3 orang

b. Data sekunder, yaitu berupa dokumendokumen atau literatur-literatur dari Badan Pusat Statistik (BPS), internet, surat kabar, jurnal dan lain sebagainya. Pengumpulan data sekunder dilakukan dengan mengambil atau menggunakanya sebagian/seluruhnya dari sekumpulan data yang telah dicatat ataudilaporkan.

\section{HASIL DAN PEMBAHASAN}

Peran adalah suatu sikap atau perilaku yang diharapkan oleh banyak orang atau sekelompok orang terhadap seseorang yang memiliki status atau kedudukan tertentu. Teori peran tidak cenderung mengklarifikasikan istilah-istilahnya menurut perilaku khusus, melainkan berdasarkan klarifikasinya pada sifat asal dari perilaku dan tujuannya (motivasinya). Sehingga, wujud perilaku peran dapat digolongkan misalnya kedalam jenis hasil kerja, hasil sekolah, hasil olahraga pendisiplinan anak, pencari nafkah, pemeliharaan ketertiban, dan lain sebagainya (Sarwono, 2015:15).

Peran dilihat wujudnya dari tujuan dasarnya atau hasil akhirnya, terlepas dari cara mencapai tujuan atu hasil tersebut. Namun tidak menutup kemungkinan adanya cara-cara tertentu dalam suatu peran yang mendapat sanksi dari masyarakat. Suatu cara menjadi penting dalam perwujudan peran ketika cara itu bertentangan dengan aspek lain dari peran.

Pengertian Badan Usaha Milik Desa Menurut Pasal 1 Angka (6) Undang-Undang Nomor 6 Tahun 2014 Badan Usaha Milik Desa, yang selanjutnya disebut BUMDes, adalah badan usaha yang seluruh atau sebagian besar modalnya dimiliki oleh Desa melalui penyertaan secara langsung yang berasal dari kekayaan Desa yang dipisahkan guna mengelola aset, jasa pelayanan, dan usaha lainnya untuk sebesar besarnya kesejahteraan masyarakat Desa (Kamaroesid, 2015: 2).

BUMDes didirikan antara lain dalam rangka peningkatan Pendapatan Asli Desa. Berangkat dari cara pandang ini, jika pendapatan asli desa dapat diperoleh dari BUMDes, maka kondisi itu akan mendorong setiap Pemerintah Desa memberikan "goodwill" dalam merespon pendirian BUMDes (Dewi, 2012). Sebagai salah satu lembaga ekonomi yang beroperasi dipedesaan, BUMDes harus memiliki perbedaan dengan lembaga ekonomi pada umumnya. Ini dimaksudkan agar keberadaan dan kinerja BUMDes mampu memberikan kontribusi yang signifikan terhadap peningkatan kesejahteraan warga desa.

Dalam penelitian ini yang menjadi pokok masalah yang didapatkan melalui hasil observasi awal dan dituangkan dalam sub bagian bab identifikasi masalah adalah: 1) Tidak ada kontribusi nyata BUMDes dalam meningkatkan ekonomi masyarakat dan 2) BUMDes tidak mampu menciptakan usaha yang mendukung profesi masyarakat, BUMDes hanya menciptkan bisnis musiman.

Kedua masalah yang ditemukan pada saat observasi awal tersebut, oleh penulis 
dituangkan dalam kajian penelitian serta dikombinasikan dengan teori yang dikemukakan oleh Seyadi (2003:16)) dalam bentuk pertanyaan yang diajukan kepada informan dalam penelitian ini.

Penelitian ini bertujuan untuk mengetahui mengetahui bagaimana peran BUMDes dalam meningkatkan ekonomi masyarakat di Desa Ayuhula Kecamatan Dungaliyo Kabupaten Gorontalo. Pembahasan untuk masing-masing indikator adalah sebagai berikut:

a) Pembangunan dan pengembangan potensi dan kemampuan ekonomi masyarakat desa pada umumnya untuk meningkatkan kesejahteraan sosial. Pada aspek ini BUMDes Tabumopa Jaya Desa Ayuhula Kecamatan Dungaliyo Kabupaten Gorontalo belum memiliki peranan yang signifikan dibuktikan dengan hanya ada satu usaha yang dimiliki oleh BUMDes dan usaha tersebut belum sesuai dengan potensi dari desa. Berdasarkan data Badan Pusat Statistik Kabupaten Gorontalo, Desa Ayuhula Kecamatan Dungaliyo potensi desanya adalah pada perkebunan dan pertanian. Jika mengacu pada data BPS tersebut, seharusnya BUMDes Tabumopa Jaya Desa Ayuhula Kecamatan Dungaliyo mendirikan usaha yang terkait dengan usaha perkebunan dan pertanian misalnya sarana produksi pertanian (saprodi), unit simpan pinjam ataupun usaha-usaha lainnya yang terkait dengan biodang perkebunan dan pertanian.

b) Berperan secara aktif dalam upaya mempertinggi kualitas kehidupan manusia dan masyarakat.

Organisasi baik dalam masyarakat maupun tidak tentu memiliki peranan dalam tujuannya. Peran aktif BUMDes Tabumopa Jaya Desa Ayuhula Kecamatan Dungaliyo hanya pada penyediaan tenda dan kursi pada saat adanya hajatan yang dilakukan oleh masyarakat. Secara sosial adanya penyewaan tenda dan kursi ini mampu menolong masyarakat, tapi belum mampu secara aktif mendorong adanya peningkatan ekonomi masyarakat.

c) Memperkokoh perekonomian rakyat sebagai dasar kekuatan dan ketahanan perekonomian nasional dengan BUMDes sebagai pondasinya.

Konsep BUMDes adalah memperkokoh perekonomian rakyat dikarenakan pelaksanaanya diselenggarakan oleh rakyat dan untuk rakyat. Pelaksanaanya ditujukan guna memperkuat ketahanan nasional.

Hasil penelitian didaptkan bahwa BUMDes Tabumopa Jaya Desa Ayuhula Kecamatan Dungaliyo Kabupaten Gorontalo belum mampu berperan Memperkokoh perekonomian rakyat sebagai dasar kekuatan dan ketahanan perekonomian nasional dengan BUMDes sebagai pondasinya. Hal ini dapat dilihat bahwa selain BUMDes hanya mempunyai satu usaha yakni usaha penyewaan tenda dan kursi, BUMDes juga belum mampu menggerakan ekonomi masyarakat dikarenakan adanya keterbatasan modal yang dimiliki.

d) Berusaha mewujudkan dan mengembangkan perekonomian masyarakat desa.

Salah satu harapan dari kehadiran BUMDes sebagaimana yang diamanatkan dalam Undang-Undang Nomor 6 tahun 2014 yakni adanya pengembangan ekonomi masyarakat desa. Harapannya adalah BUMDes yang pengelolaannya dilakukan secara bersama antara pemerintah desa dan 
masyarakat adalah mampu menjadi fasilitator dalam mengembangkan perekonomian di desa sehingga masyarakat akan ikut terdampak atas pengembangan ekonomi tersebut.

Hasil penelitian didapatkan bahwa BUMDes Tabumopa Jaya Desa Ayuhula Kecamatan Dungaliyo Kabupaten Gorontalo belum mampu berperan Berusaha untuk mewujudkan dan mengembangkan perekonomian masyarakat desa. Hal ini dikarenakan adanya keterbatasan modal yang dimiliki oleh BUMDes dalam melakukan ekspansi usaha yang lebih mendukung pada pemenuhan harapan masyarakat berupa usaha-usaha yang terkait dengan potensi desa. Namun demikian pengurus BUMDes sudah melakukan perencanaan yang nantinya akan dilaksanakan jika telah mendapatkan modal yang cukup untuk membuka usaha yang baru.

e) Membantu para masyarakat untuk meningkatkan penghasilan sehingga dapat meningkatkan pendapatan dan kemakmuran masyarakat.

Peningkatan penghasilan dalam kemakmuran masyarakat merupakan tujuan akhir pada suatu organisasi maupun perusahaan. BUMDes merupakan lembaga yang berbasis pada perekonomian rakyat dan perekonomian kreatif. Perekonomian rakyat merupakan sistem ekonomi yang mengikutsertakan seluruh lapisan masyarakat dalam proses pembangunan dimana seluruh lapisan tersebut tanpa terkecuali sebagai penggerak pembangunan sedangkan perekonomian kreatif faktor pendukung perekonomian rakyat dalam meningkatkan pendapatan masyarakat.

Berdasarkan hasil penelitian, didapatkan bahwa BUMDes Tabumopa Jaya Desa Ayuula Kecamatan Dungaliyo Kabupaten Gorontalo belum mampu berperan dalam Membantu para masyarakat untuk meningkatkan penghasilannya sehingga dapat meningkatkan pendapatan dan kemakmuran masyarakat. Hal ini dapat dilihat adanya pesimisme dari pemerintah desa bahwa pengelola BUMDes belum mampu jika usaha yang ada di BUMDes bertambah, selain daripada itu juga bahwa BUMDes dalam usaha yang ada mampu membantu masyarakat tapi dari sisi ekonomi belum sepenuhnya dapat dilakukan oleh BUMDes.

Berdasarkan analisis diatas dapat disimpulkan bahwa peranan BUMDes Tabumopa Jaya Desa Ayuhula Kecamatan Dungaliyo dalam meningkatkan perekonomian masyarakat Desa Ayuhula Kecamatan Dungaliyo Kabupaten Gorontalo belum mampu berperan sesuai dengan peranannya.

\section{KESIMPULAN}

Berdasarkan hasil pembahasan terkait dengan Peran BUMDes dalam Meningkatkan Ekonomi Masyarakat di Desa Ayuhula Kecamatan Dungaliyo Kabupaten Gorontalo, maka dapat ditarik kesimpulan sebagai berikut: Bahwa dari 5 aspek ataupun indikator peran BUMDes dalam meningkatkan ekonomi masyarakat belum sepenuhnya berperan dengan baik. Pada aspek Membangun dan mengembangkan potensi dan kemampuan ekonomi masyarakat Desa, didapatkan bahwa usaha yang dijalankan oleh BUMDes saat ini belum sesuai dengan dengan potensi dari desa; Pada aspek berperan secara aktif dalam upaya mempertinggi kualitas kehidupan manusia dan masyarakat, didapatkan pada aspek ini secara sosial dapat membantu namu secara ekonomi belum bisa berperan; Pada aspek memperkokoh perekonomian rakyat sebagai dasar kekuatan dan ketahanan perekonomian nasional dengan BUMDes sebagai pondasinya, didapatkan 
bahwa BUMDes saat ini memiliki keterbatasan modal sehingga hal ini cukup menyulitkan dalam melakukan ekspansi usaha; Pada apsek berusaha untuk mewujudkan dan mengembangkan perekonomian masyarakat desa, didapatkan dengan adanya keterbatasan yang dimiliki BUMDes sehingga sulit untuk mengembangkan usaha yang terkait dengan potensi desa: dan pada aspek membantu para masyarakat untuk meningkatkan penghasilannya sehingga dapat meningkatkan pendapatan dan kemakmuran masyarakat, didapatkan dimana adanya pesimisme dari pemerintah desa bahwa pengelola BUMDes belum mampu jika usaha yang ada di BUMDes bertambah

\section{SARAN}

Berdasarkan hasil kesimpulan diatas, maka peneliti dapat memberikan saran sebagai berikut:

1. Pemerintah Desa selaku ex-officio (Penasehat) dari BUMDes harus lebih detail memberikan saran dan masukan ke pengurus BUMDes untuk melakukan usaha-usaha yang dapat meningkatkan ekonomi dan kesejahteraan masyarakat serta dapat memberikan kontribusi (PAD) bagi desa;
2. Pengurus BUMDes harus mampu menciptakan usaha-usaha yang lebih mendukung pada profesi masyarakat serta potensi dari desa. Sehingga usaha yang ada tersebut mampu memberikan kontribusi yang nyata bagi masyarakat.

\section{REFERENSI}

Kamaroesid Herry, 2015. Tata Cara Pendirian dan Pengelolaan BUMDES, Jakarta: Mitra Wacana media

Moleong, Lexy J. 2007 Metodologi Penelitian Kualitatif, Penerbit PT Remaja Rosdakarya. Offset, Bandung

Peraturan Pemerintah Nomor 72 Tahun 2005 tentang Desa

Peraturan Menteri Dalam Negeri Nomor 39 Tahun 2010 tentang Badan Usaha Milik Desa

Sarwono, Sarlito W., 2015, Teori-teori Psikologi Sosial, PT. Raja Grafindo Persada, Jakarta.

Seyadi. 2003. BUMDes Sebagai Alternatif Lembaga Keuangan Desa. Yogyakarta: UPP STM YKPN

Undang-Undang Nomor 23 Tahun 2014 tentang Pemerintahan Daerah 